\title{
Climate change led to the demise of 5000-year old Harrapan settlement at Dholavira: isotopic evidence from gastropod Terebralia palustris
}

\author{
TORSA SENGUPTA ${ }^{1 *}$
}

${ }^{1}$ Department of Geology and Geophysics, Indian Institute of Technology, Kharagpur 721302, India (*correspondance: torsasengupta13@gmail.com )

Remains of an ancient settlement at Dholavira located in the Rann of Kutch, Gujarat represent the evolution of a Harappan metropolis from the Early to Late cultural phases of the Indus Valley Civilization (IVC 5.2-3.9 ky BP) [1]. The hospitable climate that supported the IVC contrasts sharply with the present inhabitable landscape of the Rann. Stable isotopic studies of the carbonate phase of the estuarine gastropod shells Terebralia palustris, found in the recent mangrove sediments as well as the Dholavira ruins, show that they record ambient water composition and temperature [1]. A few of these gastropod shells from the Dholavira site was used to reconstruct the ambient hydrological regime and its seasonality during the Early to Post Harappan times. The highly negative $\delta^{18} \mathrm{O}$ values of a $4.7 \mathrm{ky}$ old $T$. palustris $\left(\delta^{18} \mathrm{O}_{\text {shell }} \sim-5.8 \%\right.$ ) suggest the presence of a glacial-fed river having $\delta^{18} \mathrm{O}_{\text {water }}$ value of about $-12 \%$ (ancient Indus distributary/Saraswati?) [1]. In contrast, the $\delta^{18} \mathrm{O}$ value of a $4.3 \mathrm{ky}$ old $T$. palustris $\left(\delta^{18} \mathrm{O}_{\text {shell }} \sim-1.9 \%\right.$ ), is similar to the values seen in modern-day shells $\left(\delta^{18} \mathrm{O}_{\text {shell }} \sim-1.5 \%\right)$. This indicates drying up of this ancient river at the onset of the global Meghalayan stage drought (4.3-4.1 ky BP) [1, 2]. An abrupt desertion of the Dholavira settlement about this time, (between Stage-V and VI) is also corroborated by archaeological evidence [1]. The $\delta^{18} \mathrm{O}$ values of yet another Dholaviran T. palustris $\left(\delta^{18} \mathrm{O}_{\text {shell }} \sim-2.8 \%\right.$ ) suggest a return to a comparatively wetter regime near the lower boundary of the Meghalayan stage drought ( $4.0 \mathrm{ky} \mathrm{BP})$.

[1] Sengupta et al. (2019) JQS DOI: 10.1002/jqs.3178. [2] Walker et al. (2019) JQS 34, 173-186. 